\title{
Determnants of Revenue Collection Efficiency and Administration: The Case of Local Government Authorties in Wolaita fZone, Ethiopia
}

\author{
Mesele Kebede Manaye, B.C.M. Patnaik, IpseetaSatpathy
}

\begin{abstract}
Tax is a pervasive element of economic life around the world. The principal objective of tax is to finance government activity. A relative objective is to accomplish certain social goals. Government use tax as a device to extract money or other valuable things from people and organizations by use of law. The Ethiopian government is no exception. The government of Ethiopia uses the revenues derived from taxation in order to maintain the federal and regional governments' budgets. The purpose of this study was to identify the factors affecting revenue collection efficiency and administration, the case of local government authorities in Wolaita zone, Ethiopia. The study used descrptive research design to collect and analyze the data. The data collected through structured questionnaires from 110 randomly selected respondents from local government authorities in the study area and the data was analyzed by using multiple regressions. The study concluded that the factors concerned with weak revenue collection efficiency and administration in local government authorities were, low revenue collection efficiency level, weak administration system, the effect of tax evasion and weak enforcement mechanism. Therefore, the study recommended for the local government authorities to improve the revenue collection and administration efficiency by ensuring all eligible tax payers file returns, have tax education programs, register and upgrade individual business, audit, and receivable administer them fairly and manage the associated risk, Enforcement existing law and in this Local government authorities must produce an enforcement procedure and practice manual.
\end{abstract}

Keywords: Revenue collection efficiency, administration system, tax evasion, government expenditure, local government authorities.

\section{I.INTRODUCTION}

Tax is a pervasive element of economic life around the world. The principal objective of tax is to finance government activity. A relative objective is to accomplish certain social goals. Government use tax as a device to extract money or other valuable things from people and organizations by use of law. The Ethiopian government is no exception. The government of Ethiopia uses the revenues derived from taxation in order to maintain the federal and regional governments' budgets.

Revised Manuscript Received on October 30, 2019.

* Correspondence Author

Mesele Kebede Manaye*, Research scholar, School of management, KIIT University

B.C.M. Patnaik, Associate Professor, School of management, KIIT University.

IpseetaSatpathy, Professor, School of management, KIIT University

(C) The Authors. Published by Blue Eyes Intelligence Engineering and Sciences Publication (BEIESP). This is an open access article under the CC BY-NC-ND license (http://creativecommons.org/licenses/by-nc-nd/4.0/)

The Ethiopia government is strongly committed to achieving the middle-income status for Ethiopia by 2020/23. This is reflected in the GTP 1 and11 with its strategic pillars of sustain the rapid, broad based and equitable economic growth and development, increase the revenue collection and administration capacity efficiency to reach the economic production possibility frontier though concurrently improving quality, productivity and competitiveness of productive sector. Moreover, the strategic pillars are focused on speed up and catalysis transformation of the demotic revenue collection and generally broad based real economic growth. (MOFECM, 2005) Currently, Wolaita zone revenue authorities are one of the zones in Southern Nations, Nationalities, and peoples' of Ethiopia. It was established on July 2008, were separated from finance and economic development. It established for the purpose of enhancing the mobilization of government revenues, while providing effective tax administration and sustainability in revenue collection. (WFED 2015/2016)

One of the major determinants of tax payer's voluntary compliance leads to inefficiency in tax administration and collection efforts by tax authorities and this further leading to tax avoidance and evasion. Another important factor for inefficiency in collecting and administering revenue is corruption. (Rosen and Gayer, 2008). Insufficient revenue to finance improvements in service delivery, and provide new and better infrastructure, and facilities is the core problem that is identified by the Revenue collection efficiency and administration. The main causes for the core problem are diverse and complex. Some of them are: i) revenue collecting institutional and human source related problems; ii) Poor administration of own source revenues i.e. inadequate tax assessment and auditing, low revenue collection, inappropriate accounting system, poor enforcement, and weak debt collection ; iv) Weak customer relations that is manifested by negative attitudes of customers, inadequate awareness of residents and tax payers; v) Ineffective data management and unavailability of appropriate data, unreliable and incorrect data, inability to use data effectively, poor integration of data bases and inter-linkages between agencies, and irregular updating of data.Currently, Wolaita zone revenue authorities are one of the zones in Southern Nations, Nationalities, and peoples' of Ethiopia. It was established on July 2008, were separated from finance and economic development. 
Determnants of Revenue Collection Efficiency and Administration: The Case of Local Government Authorties in

\section{Wolaita fZone, Ethiopia}

It established for the purpose of enhancing the mobilization of government revenues, while providing effective tax administration and sustainability in revenue collection. (WFED 2015/2016)

\section{II.OBJCTIVES OF THE STUDY}

The purpose of this study is to identify the determinants of revenue collection efficiency and administration in Wolaita zone revenue authorities.

\section{Specific objectives}

1. To identify the determinants of revenue collection efficiency and administration in local government authorities in Wolaita zone.

2. To investigate their relationship with revenue collection and administration efficiency in Local government authorities.

\section{III.RESEARCH HYPOTHESES}

H1 - There is no relationship between Low revenue collection efficiency rate and revenue collection efficiency and administration in local government authorities.

H2 - There is no relationship between weak administration system and revenue collection efficiency and administration in local government authorities.

H3 - There is no relationship between Effects of tax evasion and revenue collection efficiency and administration in local government authorities.

$$
n=\frac{n_{0}}{1-\left(n_{0}-1\right) / N}
$$

H4- There is no relationship between lack of enforcement mechanism and revenue collection efficiency and administration in local government authorities.

\section{IV.RESEARCH METHODOLOGY}

Research Design

The type of research design employed under this study was descriptive.

Research Approach

Quantitative research approaches were used for this study, because the quantitative approach is to discover answers to questions through application of scientific procedures.

\section{Sample Design}

Sampling is a method of selecting sampling units to be included in the study. To conduct the study thoroughly probabilistic sampling techniques will be used. Probability sampling will used to minimize biases and to ensure representativeness of the study.

Sampling Technique

To conduct the study, probabilistic sampling techniques were employed. Probability sampling technique was used for the selection of respondents. In this case to draw units from the sample frame, systematic random sampling was used. Since systematic random sampling technique of probability sampling is simple, less costly and more convenient method to pick representatives that ensure inclusion in the sample.

Sample Size
Sampling is a process of selecting representative element or samples from the population. Conducting a research on the total population is the most accurate means but constraint on time resource and its manageability make researcher to select sample from the employments. Hence, determining sample size that would represent the total population is essential. The respondents were the employees of revenue authorities of the Wolaita Zone. The zone has 12 rural districts and 3 Town administrations and composed of peoples of different sexes, ages, professionals, and educational background. As stated above, totally 110 respondents were selected from Wolaita Zone tax revenue collection authorities to conduct this research. For populations that are large, the equation developed by IBD to yield representative proportion is as follows

For infinite population

$$
\mathrm{N}=151-1+151(.05)
$$

$$
=151 / 1+151(.0025)
$$

$=151 / 1+0.377$

$$
=151 / 1.377=109.6
$$

Where: $n$ is sample size

$$
\mathrm{Z}^{2}=\text { required level of confidence }
$$

as 1- $\alpha P=$ estimated proportion of

$$
\mathbf{n}=\frac{z^{2} p q}{e^{2}}=\frac{z^{2} p q}{e^{2}}
$$

Where $n_{0}$ sample size for infinite population and $N$ is population size.

Table 3.1 Sampling Size, Determination And Sampling Technique

\begin{tabular}{|l|l|l|}
\hline Types of respondents & $\begin{array}{l}\text { Target } \\
\text { population }\end{array}$ & $\begin{array}{l}\text { Optimal } \\
\text { sample size }\end{array}$ \\
\hline Top management & 10 & 7 \\
\hline $\begin{array}{l}\text { technical revenue } \\
\text { collector staff }\end{array}$ & 51 & 37 \\
\hline $\begin{array}{l}\text { technical staff } \\
\text { accountant }\end{array}$ & 90 & 66 \\
\hline Total & 151 & 110 \\
\hline
\end{tabular}

Types and sources of data

In this study, the researcher used primary data. The primary data obtained from questioner which was distributed for sample population.

Primary Data Sources

Primary data were obtained by using questionnaire and the questionnaire encompassed both close and open ended questions. For this study, primary data was being gathered from employment, and key informants. 
Data collection procedures

In this study, instruments were employed to measure three continuous independent variables and one continuous dependent variable. These are outlined below: -

Data Analysis and Interpretation

The data were analyzed by multiple regressions, Factors Affecting Revenue Collection Efficiency and administration. The following model was applied:

$\mathrm{Y}=\beta 0+\beta 1 \mathrm{X} 1+\beta 2 \mathrm{X} 2+\beta 3 \mathrm{X} 3+\beta 4 \mathrm{X} 4+\varepsilon$

Where: $\mathrm{Y}=$ Revenue collection efficiency and administration X1 = Revenue collection efficiency rate

\section{X2 = Administration capacity}

$\mathrm{X} 3$ = Control tax evasion

X3 = Evaluate enforcement

mechanism $\varepsilon=$ Error term the model

The model is first subjected to F-test to establish whether the variables were jointly significant. T-tests were further computed for the individual variables' coefficients to determine their significance in the model. Null hypothesis was accepted or rejected.

\section{V.RESULTS AND DISCUSSION}

Introduction

This study investigated for five years of study period on the factors affecting revenue collection efficiency and administration in local government authorities with specific reference to the six out of fifteen recognized local government authorities in wolaita zone. In the first place, the study sought to determine factors which are strengthen revenue collection efficiency in local government authorities. Secondly, the study to know the administration system that affects capacitating revenue collection efficiency in the area. Thirdly to find out the tax evasion is among the factors affecting revenue collection efficiency. Finally, the study sought to evaluate the setback that affects the application of enforcement, and capacitating the revenue collection efficiency in the whole revenue collection and administration process.

The data was presented in tables beginning with the sample characteristics and then research questions that were formulated to guide the research .The first part of the chapter considers the demographic background of the respondents, focusing on sex, education level, place of work (district/ city) and position held. The second part represents the findings from the study in relation to the research questions.

\section{DESCRIPTIVE ANALYSIS}

DETERMINANTS OF REVENUE COLLECTION

EFFICIENCY AND ADMINISTRATION IN LOCAL GOVERNMENT AUTHORTIES

The intention of knowing these factors was to understand the ways of revenue collection efficiency and administration in the area of study. The results showed that the majority suggested low revenue collection efficiency rates, weak administration, others were, the effect of tax evasion and lack of enforcement mechanism. Table 4.12 present the results from respondents who contributed to the following research question: what factors lead to increased variance in revenue collection efficiency and administration in local government authorities?

\section{VI.RELATIONSHIP AMONG VARIABLES}

The researcher wanted to determine the statistical significance of the attempted prediction and the strength of association between the single dependent variable and the multiple independent variables. for the purpose of this investigation there were four continuous independent variables and one continuous dependent variable. Hence, for testing the relationship among them regression analysis was performed on the following SPSS output was obtained as follows.

Table 4.24 descriptive statistics

\begin{tabular}{|l|r|r|l|}
\hline & Mean & \multicolumn{1}{|l|}{$\begin{array}{l}\text { Std. } \\
\text { Deviati } \\
\text { on }\end{array}$} & N \\
\hline Revenue & 3.69 & .775 & 110 \\
collection & 3.60 & .804 & 110 \\
efficiency and & 4.02 & .857 & 110 \\
administration & 4.26 & .700 & 110 \\
revenue & 3.88 & .646 & 110 \\
collection & & & \\
efficiency & & & \\
rate & & & \\
enforcement & & & \\
mechanism & & & \\
tax evasion & & \\
administration efficiency & & & \\
\hline
\end{tabular}

Model Summary

\begin{tabular}{|l|c|l|l|r|}
\hline $\begin{array}{l}\text { Mod } \\
\text { el }\end{array}$ & $\mathrm{R}$ & $\begin{array}{l}\mathrm{R} \\
\text { Square }\end{array}$ & $\begin{array}{r}\text { Adjusted } \\
\text { R Square }\end{array}$ & $\begin{array}{r}\text { Std. Error of } \\
\text { the Estimate }\end{array}$ \\
\hline 1 & $.839^{\mathrm{a}}$ & .657 & .670 & .365 \\
\hline
\end{tabular}

a. Predictors: (Constant),Low revenue collection efficiency rate, Weak administration system, Effects of tax evasion, lack of enforcement mechanism

b. Revenue collection efficiency and administration

c. ANOVA $^{\mathrm{a}}$

\begin{tabular}{|l|r|r|r|r|l|}
\hline Model & $\begin{array}{r}\text { Sum of } \\
\text { Square } \\
\text { s }\end{array}$ & $\begin{array}{l}\text { d } \\
\text { fean }\end{array}$ & $\begin{array}{r}\text { M } \\
\text { Square }\end{array}$ & Sig. \\
\hline Regression & 27.180 & 8 & 6.648 & 42.035 & $.000^{\mathrm{b}}$ \\
1 Residual & 11.311 & 101 & .439 & & \\
Total & 65.491 & 109 & & & \\
\hline
\end{tabular}

a. dependent variable: Revenue collection efficiency and administration 


\section{Wolaita fZone, Ethiopia}

b. Predictors: (Constant),Low revenue collection efficiency rate, weak administration system, Effects of tax evasion, lack of enforcement mechanism

Table 4.36 regression coefficient

\begin{tabular}{|c|c|c|c|c|c|}
\hline \multirow[t]{2}{*}{ Model } & \multicolumn{2}{|c|}{$\begin{array}{l}\text { Unstandardi } \\
\text { zed } \\
\text { Coefficients }\end{array}$} & \multirow{2}{*}{$\begin{array}{l}\text { Standardi } \\
\text { zed } \\
\text { Coefficie } \\
\text { nts } \\
\text { Beta }\end{array}$} & \multirow[t]{2}{*}{$\mathrm{T}$} & \multirow[t]{2}{*}{ Sig } \\
\hline & B & $\begin{array}{l}\text { St } \\
\text { d. } \\
\text { Er } \\
\text { ror }\end{array}$ & & & \\
\hline $\begin{array}{l}\text { revenu } \\
\text { e } \\
\text { collecti } \\
\text { on } \\
\text { efficie } \\
\text { ncy } \\
\text { rate }\end{array}$ & $\begin{array}{r}.20 \\
3\end{array}$ & .082 & 211. & $\begin{array}{r}2.4 \\
71\end{array}$ & $\begin{array}{r}.00 \\
0\end{array}$ \\
\hline $\begin{array}{l}\text { enforceme } \\
\text { nt } \\
\text { mechanism }\end{array}$ & $\begin{array}{r}.22 \\
6\end{array}$ & .077 & 249 & $\begin{array}{r}2.9 \\
36\end{array}$ & $\begin{array}{r}.00 \\
4\end{array}$ \\
\hline $\begin{array}{l}\text { Tax } \\
\text { evasion }\end{array}$ & $\begin{array}{r}.10 \\
8\end{array}$ & .095 & .098. & $\begin{array}{r}1.1 \\
32\end{array}$ & $\begin{array}{r}.26 \\
0\end{array}$ \\
\hline $\begin{array}{l}\text { administra } \\
\text { tion } \\
\text { system }\end{array}$ & $\begin{array}{r}.44 \\
8\end{array}$ & .103 & .373 & $\begin{array}{r}4.3 \\
62\end{array}$ & $\begin{array}{r}.00 \\
0\end{array}$ \\
\hline
\end{tabular}

a. Dependent Variable: Revenue collection efficiency and administration

Thus, as shown in the above table, a unit increases in the revenue collection efficiency rates beings about $21.1 \%$ increase in revenue collection and administration. The Tvalue (2.471) also implies that the revenue collection efficiency rates significant (at $10 \%$ level of significance) affects revenue collection and administration. The some way a unit increase in tax administration system changes the revenue collection and administration by $37.3 \%$ and, the effect very strong as shown by the T-value i,e 4.362 which is significant (at $10 \%$ level of significance). Similarly, a unit increase in the enforcement mechanism changes the revenue collection by $24.9 \%$.and the effect is strong as it is significant (at $10 \%$ level of significance) as implied by the T- value i.e 2.936. Again, a unit increase in tax evasion beings about approximately 9.8 increases in revenue collection and administration through changes it is not significant. The independent variables are explaining 65.5 of variance in dependent variable revenue collection efficiency rate, administration efficiency, tax evasion. The best predictor of dependent variable is low revenue collection efficiency rates, weak administration system and enforcement mechanism $r=0.710 ; \mathrm{p}<0.001$. Except the effects of tax evasion which do not have significant contribution in explaining the dependent variable $(p>0.05$, the remaining variables have significant contribution in explaining the dependent variable $(\mathrm{p}<0.01)$.

The data were analyzed by multiple regressions, usingindependent variable (low revenue collection efficiency rates, weak administration system, effect of tax evasion and enforcement mechanism and revenue collection efficiency and administration. The regression model was better $(\mathrm{R}$-square $=65.5)$, but the overall relationship was significant $(\mathrm{F}=42.629, \mathrm{p}<0.001)$. With other variables held constant, revenue collection efficiency and administration was positively related to revenue collection efficiency rate, weak administration system and enforcement mechanism by law, but negatively related to affect of tax evasion to revenue collection efficiency and administration.

\section{VII.CONCLUSIONS AND RECOMMENDATIONS}

\section{CONCLUSIONS}

In the first place, the study noticed some weakness in the revenue collection efficiency process in local government authorities. The finding revealed that most of local government authorities don't meet its revenue collection efficiency goals. The level of performance in revenue collection efficiency in local government authorities were below $100 \%$. Also, the study discovered revenue collection efficiency that was not being sufficiently explored by the local government authorities.

Secondly, the study was conduct on aspects of tax administration comparison tax registration, audit and receivable management these leakages are as result of weak administration. Here the most challenging problems for small scale business, they don't maintain books of accounts to assess their real income from their ordinary course of business. This again resulted in assessing their performance based on personal estimations, rather than based on their books of records. this created collection inefficiencies, and this resulted in tax evasion and cumulative arrears are significant.

Thirdly, the study discovered factors that affect revenue collection efficiency and administration in LGAS. The results showed that the major factors leading to increased in revenue collection administration were low revenue collection efficiency rate, weak administration, lack of enforcement by law and the effect of tax evasion. The best predictor of independent variable is low revenue collection rates, weak administration and lack of enforcement by law charged by local government authorities should which is having regression coefficient of $r=0.710 ; p<0.001$.

Lastly, the study discovered contribution from the participants who explained the measure to administer revenue collection and efficiency process. As presented on table 4.18 the measures including responses mentioned were high motivation revenue staff $18.2 \%$, ethical discipline of revenue collector $17.2 \%$, modernizing the revenue collection activities in computerized ways $4.6 \%$ and the use of LGAs man power instead of training should be given to boost the efficiency of the revenue collection system $60 \%$.

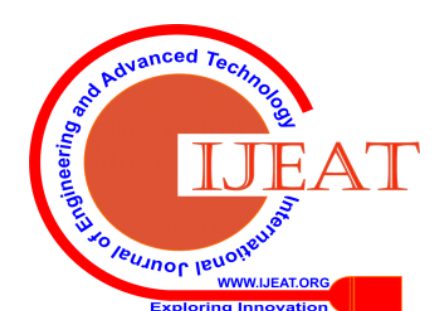




\section{RECOMMENDATIONS}

Local government authorities should be aware of the factors that affect revenue collection efficiency and administration process. In summary to ensure that government has enough revenue to undertake it activities, LGAs needs to the following.

1. Ensure more efficient tax collection system adding further burden upon the tax payers.

2. For increasing tax coverage, a comprehensive list and efficiently organized to register and upgrade are essential for optimizing tax collection efficiency

3. Educate a strong and continuous awareness campaign with a clear and simple tax explanation usage is fundamental to increase tax compliance everyone in LGAs on the importance of paying tax.

4. Improve the revenue administration system that is LGAs must ensure all eligible tax payers file returns, have tax education programs, register and upgrade individual business, audit, and receivable administer them fairly and manage the associated risk.

5. Enforcement existing law and in this LGAs must produce an enforce procedure and practice manual. The other chosen enforcement mechanism was to call for the LGAs administration seeking its political enforcement support. Moreover, it diplomatically agitates and imposes political pressure that, has become more effective than other enforcement mechanisms to support revenue collection efficiency.

6. Legal frameworks should be fair and enforced. The illegal traders in the LGAS have become headache to those who are performing their business legally due to the existence of rules of law and systems, and also the responsibility of the revenue to bring them to formal tax net. This encourages the legal traders to the payment of their tax liability on one hand and become increase the revenue potential on the other hand.

\section{REFERENCES}

1. Wolaita Zone Revenue Authority (2015) Statistical Bulletin, Tax Collection (2012-2016) Fiscal Years, annual revenue collection report, Wolaita soddo, Ethiopia.

2. Wolaita Zone Finance and Economic development Department (2015/16) Socio-Economic and Geo-Spatial data, revenue collection and expenditure (2012-2016) Fiscal Years, annual Statistical report, Wolaita soddo, Ethiopia.

3. Wolaita Sodo City Administration (July 2017) Revenue Enhancement plane (2000-2002) With Strategies of Enhancemets, Wolaita soddo, Ethiopia.

4. Demirew Getachew (2004), Tax Reform program in Ethiopia and Progress to Date, Paper Presented to the Second International Conference on the Ethiopian Economy, held 3-5 June 2004 at the United Nations Conference center, Addis Ababa, Ethiopia.

5. Taxation in modern nation-states benefits the majority of the population and social development (Oliver Wendell Holmes, Jr.)

6. The benefit approach was initially developed by Wicksell (1896) and Lindahl, two economists of the Stockholm School (1919),

7. Adom (1998), said there should be a provision in the tax laws to establish a special court to try tax cases

8. Ethiopian Delegates 2006, 'Value added tax in Ethiopia', Speech at the 9th Value Added Tax Administration in Africa (VADA) Forum, Zimbabwe.

9. Adereti, S.A., Sanni M.R. \& Adesina J.A. (2011). Value Added Tax and economic Growth of Nigeria. European Journal of Humanities and Social Science. 10(1), 456-471.

10. ERCA(2011) Statistical Bulletin, On Foreign Trade and federal Duty and Tax Collection(2005/06-2009/10) 10 Ethiopian Fiscal Years, A publication of Macro Data Processing Analysis Team, Addis Ababa
,Ethiopia.

11. FDRE 2002, 'Value Added Tax Proclamation No. 285/2002', Federal Negarit Gazeta, Addis Ababa, Ethiopia. FDRE 1995, Constitution of the Federal Democratic Republic of Ethiopia, the Ethiopian Federal Government, Addis Ababa.

12. Gills,Malcolm,Carls Shoup and Gerado Sicat(1990), Value Added Taxation in Developing Countries. A World bank Symposium.(Washington: The World bank Symposium)

13. Hancock, Dora (1995), Taxation: Policy and Practice. Chapman and Hall, 3rd Edition

14. Harvey S. Rosen (1995), Public Finance, Value Added Tax Implementation Issues. The United states revenue system.

15. H.L. Bhatia ( 2003 ), Public Finance, 24th revised edition, department of Economics, shriRam College of Commerce, University of delhi, Vikas Publishing House Pvt Ltd.

16. IMF 1989, 'Tax administration in developing countries: Strategies and tools of implementation', Policy, Planning and Research Working Papers (WPS 43), background paper for the 1988 World Development Report 